\title{
A COMPARISON OF PROBLEM BEHAVIOURS OF STUDENTS WITH VISUAL IMPAIRMENTS AND TYPICALLY DEVELOPING STUDENTS*
}

\author{
Fatih Emrah Demir ${ }^{\star 1}$, Selda Ozdemir ${ }^{2}$ \\ ${ }^{1}$ Res. Asst., Gazi University, TURKEY, fatihemrah@gazi.edu.tr \\ ${ }^{2}$ Assoc. Prof., Gazi University, TURKEY, seldaozdemir@gazi.edu.tr \\ ${ }^{*}$ Corresponding author
}

\begin{abstract}
The purpose of this study was to compare the problem behaviours of students with visual impairments with typically developing students. The study groups consisted of 64 students with visual impairments and 68 typically developing students ranged from the first to fourth grade. The Social Skills Rating Scale Teacher Form was used to evaluate the problem behaviours of the groups. The results of the study indicated that problem behaviours of students with visual impairments were higher than typically developing peers' problem behaviours. The results of the study also indicated that age, gender and the degree of visual impairments (having low vision or severe visual impairments) had no effect on the problem behaviours of students with visual impairments. Findings of this study were discussed and suggestions for future research and practice were provided.
\end{abstract}

Keywords: Problem behaviours, visual impairments, low vision, severe visual impairments.

\section{INTRODUCTION}

School, as a system, is an essential environment in which students, parents, teachers, and other community members have opportunities to learn, and progress through. Students spend a significant amount of their time at schools. Teachers and other professionals at schools provide their students with learning environments that are positive, and predictable (Sugai, et al., 2000). However, teachers may face some challenges while supporting their students in different developmental fields. Managing problem behaviours is one of the challenges teachers may face at schools. Students who have significant problem behaviours may have serious problems at daily life as well (Elgar, Arlett, \& Groves, 2003). It is essential to work with different professionals as a part of a multi-disciplinary team to intervene the problem behaviours of students as early as possible (Ageranioti-Bélanger, Brunet, D’Anjou, Tellier, Boivin, \& Gauthier, 2012).

Problem behaviours have been defined by different researchers in different fields. Describing problem behaviours of students is complicated, because different professionals have different perspectives while explaining problem behaviours. A universally accepted definition of problem behaviours has not been reached yet (Aykir, 2010). Sucuoglu and Kargin (2006) define problem behaviours as behaviours that influence the social interaction negatively and may harm the student him/herself. All students would engage problem behaviors from time to time. However, studies showed that students with special needs display more problem behaviours than their typically developing peers (Sucuoglu \& Kargin, 2005). Researchers also showed that problem behaviours are negatively correlates with social skills and academic competence 
(Sucuoglu \& Ozokcu, 2005). In a study, Sucuoglu and Kargin (2006) emphasize that social skills, problem behaviours and academic competence are interrelated to each other.

Cicchetti and Toth (1990) state that problem behaviours could be classified into two main categories. The two main categories of problem behaviours are internalizing and externalizing behaviours. This classification is widely accepted in the literature. Ozdemir (2010) states that while externalizing behaviours includes aggressive behaviours, oppositional defiant behaviours, and social problems; internalizing behaviours comprise mental and emotional conflicts such as intensive anxiety, causeless fear and depression. Students who exhibit externalizing behaviours usually oppose values and rules of different contexts such as home and school which are widely accepted (Walker, Ramsey, and Gresham, 2004). Exhibiting externalizing behaviours in childhood could be a predictor of more complicated antisocial behaviours displayed in adolescence. In a longitudinal project, Kenneth, Chen, Mc Dougall, Bowker, and McKinnon (1995) examined childhood social withdrawal and aggression as a predictive of adolescent maladaptation, and reported that it is linked to social and emotional outcomes that are associated with later aggression and social withdrawal. Kenneth et al. (1995) used behavioural observations, peer assessments and teacher ratings to collect their study data. Findings of the study also indicated that childhood social withdrawal uniquely and significantly contributed to the prediction of adolescent loneliness, feeling of insecurity, and low self-esteem. Results also showed that aggression predicted adolescents' delinquent activity as well.

The second category of the problem behaviours are internalizing behaviours. Although most externalizing behaviours can be observed, internalizing behaviours may not be recognized in the same way. Internalizing behaviours may harm a person him/herself but not disturb others (Welcome, 2013). Vossekuil, Fein, Reddy, Borum, and Modzeleski (2002) found that children who display internalizing problems such as anxiety and depression in their earlier lives tend to exhibit externalizing behaviours in their later childhood. Such findings are important in regard to its reflection on educational systems. Intervening the internalizing problems earlier in life may prevent the development of externalizing problems in later childhood. Ozdemir (2013) emphasizes the transitivity between internalizing and externalizing problem behaviours. This transitivity should be taken into consideration in order to intervene the problems as early as possible. Perle, Levine, Odland, Ketterer, Cannon, and Marker (2013) investigated an association between internalizing symptomology and risky behaviours. Internalizing symptoms (withdrawn/depressed and anxious/ depressed), measured with the Child Behavior Checklist (CBCL), were examined as related to the development of externalizing problems, a pathway to risky behaviours in Perle et al.'s (2013) study. Findings of the study indicated that internalizing symptoms significantly related to externalizing behaviours, with "anxious/depressed" accounting for the greatest proportion of the variance. Study results also showed the benefits of identifying and intervening internalizing problems early in life, which may decrease occurrences of externalizing and other problem behaviours such as substance abuse. It could be considered that internalizing, externalizing and other problem behaviours are all closely intertwined. Therefore, interventions designed to decrease internalizing and externalizing problem behaviours and increase appropriate social skills should be one of the public mental health and educational concerns.

Sucuoglu (2003) states that problem behaviours may become serious barriers for students with special needs to be accepted by their groups. Studies showed that students with special needs may exhibit higher problem behaviours then their typically developing peers (Orhan, 2010; Sucuoglu, 2005). Many researchers found that students with developmental delays display more problem behaviours than their typically developing peers (Aykir, 2010; Dekker, Koot, Ende, \& Verhulst, 2002; Yosumaz, 2013). Students with visual impairments are also at risk for developing more problem behaviours than their typically developing peers (Ozkubat, 2010). Ozkubat and Ozdemir (2012) found that social skills of students with visual impairments were significantly lower than their typically developing peers. Other studies conducted in Turkey also suggested that students with visual impairments exhibit higher social skills deficits (Ozdemir, 2009; Ozdemir \& Ataman, 2010; Ozdemir et al. 2011). Alimovic (2013) conducted a comprehensive study and compared the emotional and behavioural problems of students with intellectual disabilities, visual impairments, multiple disabilities, and typically developing students. Study results showed that children with visual impairments, intellectual disabilities, and multiple disabilities had higher problem behaviours than their typically developing peers based on family reports. Considering the negative correlations between social skills and behavioural problems (Sucuoglu \& Ozokcu, 2005) and the assumptions related to the functions of exhibiting problem behaviours such as gaining attention, avoiding completing a difficult task, and getting sensory stimulation (Vuran, 2013), the negative role of social skills deficits on the development of problem behaviours should be remarked. Researchers examining problem behaviours of students with visual impairments are few in the literature. However, the prevalence of behavioural and emotional problems in students with visual impairments are found to be $26 \%$ to $57 \%$ more than sighted students (Alimovic, 2013). Studies that explore problem behaviours of students with visual impairments in Turkey is important in order to plan and implement 
interventions to decrease problem behaviours of students with visual impairments in Turkey. Thus, current study is important in owing to examining the problem behaviour profiles of students with visual impairments in order to build the evidence base needed to develop effective interventions for students with visual impairments.

The purpose of this study was to compare the problem behaviours of students with visual impairments with typically developing peers. The study questions of this study are:

1. Do problem behaviours of students with visual impairments differ from their typically developing peers' problem behaviours?

2. Do problem behaviours of students with visual impairments differ based on students' age?

3. Do problem behaviours of students with visual impairments differ based on students' grade levels?

4. Do problem behaviours of students with visual impairments differ based on students' gender?

5. Do problem behaviours of students with visual impairments differ based on the degree of students' visual impairments?

\section{METHOD}

A descriptive method was used in the study in order to compare the problem behaviours of students with visual impairments with typically developing peers. The Social Skills Rating Scale (SSRS) Teacher Form (Gresham \& Elliot, 1990; Sucuoglu \& Ozokcu, 2005), and a Personal Information Form were used to collect the study data. The data obtained from the SSRS Teacher Form and the Personal Information Form were analysed. Initially, a reliability analysis was performed for the Problem Behaviours Scale and its subtests. After reliability analysis had showed that the Problem Behaviours Scale and its subtest had been reliable to use in the study, statistical analysis was conducted. A Kolmogorov-Smirnov normality test was adopted for the Problem Behaviours Scale and its subtests. Nonparametric tests were used as the Kolmogorov-Smirnov test showed no normality assumption. A Mann Whitney-U test was used to analyse statistically significant differences between two independent groups. A Kruskal Wallis test was performed to analyse whether there were statistically significant differences between more than two independent groups.

\subsection{Participants}

The participants of this study were 132 students. 64 of the participants were students with visual impairments and 68 participants were typically developing students. The participants' ages ranged from 7 to 11 in both groups. The participants of the study attended to primary schools in Ankara, capital city of Turkey.

Two study groups were compared in the study. The first study group consisted 64 students with visual impairments and the second group consisted 68 typically developing students. The distribution of the participants by age, gender, grade levels and disability status (having visual impairments or having typical development) were showed on Table 1.

Table 1. The distribution of the participants by age, gender and grade levels.

\begin{tabular}{|l|c|c|c|c|}
\hline & \multicolumn{2}{|c|}{$\begin{array}{c}\text { Students with visual } \\
\text { impairments }\end{array}$} & \multicolumn{2}{|c|}{$\begin{array}{c}\text { Typically Developing } \\
\text { Students }\end{array}$} \\
\hline Grade & N & $\%$ & N & $\%$ \\
\hline 1. grade & & & & \\
\hline 2. grade & 8 & 12,5 & 15 & 22,1 \\
\hline 3.grade & 18 & 28,1 & 18 & 26,5 \\
\hline 4. grade & 15 & 23,4 & 18 & 26,5 \\
\hline Age & 23 & 35,9 & 17 & 25,0 \\
\hline 7 & $(9,16 \pm 1,300)$ & $(8,54 \pm 1,165)$ \\
\hline 8 & 6 & 9,4 & 17 & 25,0 \\
\hline 9 & 17 & 26,6 & 16 & 23,5 \\
\hline
\end{tabular}




\begin{tabular}{|l|c|c|c|c|}
\hline 10 & 11 & 17,2 & 17 & 25,0 \\
\hline 11 & 14 & 21,9 & 1 & 1,5 \\
\hline Gender & & & & \\
\hline Female & 28 & 43,8 & 33 & 48,5 \\
\hline Male & 36 & 56,3 & 35 & 51,5 \\
\hline Total & $\mathbf{6 4}$ & $\mathbf{1 0 0 , 0}$ & $\mathbf{6 8}$ & $\mathbf{1 0 0 , 0}$ \\
\hline
\end{tabular}

One of the study groups in this study were students with visual impairments. The distribution of students with visual impairments based on their degree of visual impairments (low vision or severe visual impairments) was showed in Table 2.

Table 2. The distribution of students with visual impairments by the degree of visual impairments.

\begin{tabular}{|l|c|c|}
\hline & N & $\%$ \\
\hline Degree of visual impairments & & \\
\hline Low vision & 30 & 46,9 \\
\hline Severe visual impairment & 34 & 53,1 \\
\hline Total & 64 & 100 \\
\hline
\end{tabular}

Table 2 shows that 30 participating students with visual impairments had low vision whereas 34 participants of the group with visual impairments had severe visual impairments. Overall number of students with visual impairments was 64 . The degree of visual impairments of students was obtained from teachers' data.

\subsection{Procedure}

A written official permission letter was obtained from Turkey Ministry of National Education in order to collect the study data using the SSRS based on participating teachers work in primary schools.

Field visits were made to school administrators and teachers. In these meetings, the purpose of the study was explained to both teachers and administrators. Authors also arranged meetings with participating teachers to introduce the SSRS and to explain how to fill the scale. Questions of teachers and administrators were answered related to the study and the study procedure.

A random sampling technique was used for the selection of the sample group of typically developing students. Teachers of typically developing students selected participants randomly from the student class lists. Teachers of students with visual impairments who work at the schools for students with visual impairments filled the Problem Behaviours Scale for all of their students except children having an additional disability. Students with additional disabilities were excluded from the study. Scales which incorrectly filled by some teachers were omitted from this study. A total of 132 participants' data were included in the study.

\subsection{Data Collection Instruments}

In this study, the SSRS (Gresham \& Elliot, 1990; Sucuoglu \& Ozokcu, 2005) was used to collect the study data. The Problem Behaviours Scale which is one of the scales in the SSRS and the Personal Information Form were used to collect the study data. The Problem Behaviours Scale and the Personal Information Form were scored by the teachers of both groups for each participant.

\subsubsection{The Problem Behaviours Scale}

Gresham and Elliot (1990) developed the Social Skills Rating Scale which includes three scales. These scales are Social Skills Scale, Problem Behaviours Scale and Academic Competence Scale.

Sucuoglu and Ozokcu (2005) translated the form into Turkish and conducted reliability and validity analysis. Sucuoglu and Ozokcu (2005) conducted the study with 53 inclusive education students and 560 typically developing students. Researchers used the Cronbach alpha coefficient to test the reliability. The Cronbach alpha was found to be .90 for the overall scale.

The Problem Behaviours Scale includes two subscales. These are externalizing and internalizing sub-scales. The Problem Behaviours Scale includes 18 items. For each item, teachers score the frequency of the 
problem behaviours of students on a three point likert scale ranged from 0 (never), to 1 (sometimes), to 3 (very often) (Sucuoglu \& Ozokcu, 2005).

\subsubsection{Personal Information Form}

A Personal Information Form which was developed by the authors was used to collect the study data. Students' demographic data was obtained via the use of Personal Information Form. With the use of the Personal Information Form, disability status (having a visual impairment or being typically developing) and the degrees of the visual impairments (low vision or severe visual impairments) for students with visual impairments were also obtained.

\section{RESULTS}

\subsection{Reliability Analysis Of The Problem Behaviours Scale And Its Subscales}

Reliability results of the Problem Behaviours Scale and the sub-scales of the Problem Behaviours Scale were shown in Table 3.

Table 3. Reliability analysis of the problem behaviours scale and its subscales.

\begin{tabular}{|l|c|c|c|}
\hline & $\begin{array}{c}\text { Number of } \\
\text { Items }\end{array}$ & Cronbach Alfa & Reliability Level \\
\hline Problem Behaviours Scale & 18 & 0,900 & Highly Reliable \\
\hline Externalizing Behaviours & 12 & 0,902 & Highly Reliable \\
Internalizing Behaviours & 6 & 0,735 & Reliable \\
\hline
\end{tabular}

Reliability analysis for the Problem Behaviours Scale and its sub-scales was conducted using the Cronbach alpha coefficient. Table 3. shows that reliability analysis indicated Problem Behaviours Scale $(\alpha=0,900)$ and Externalizing $(0,902)$, Internalizing $(0,735)$ sub-scales are reliable instruments to use in this study.

\subsection{Do Problem Behaviours Of Students With Visual Impairments Differ From Problem Behaviors Of Their Typically Developing Peers?}

The Problem Behaviours Scale scores of students with visual impairments were compared to their typically developing peers' problem behaviours scores. A Mann Whitney-U test was used to examine the significant differences between students with visual impairments and typically developing students. The results were shown in Table 4.

Table 4. Comparison of problem behaviours of students with visual impairments and typically developing students.

\begin{tabular}{|c|c|c|c|c|c|}
\hline Scales and subscales & Group & $\mathrm{N}$ & Median & Z & $p$ \\
\hline \multirow{2}{*}{ Externalizing Behaviours } & SVI & 59 & $7(0-24)$ & \multirow{2}{*}{$-3,142$} & \multirow{2}{*}{$0,002^{\star \star}$} \\
\hline & TDS & 67 & $3(0-24)$ & & \\
\hline \multirow{2}{*}{ Internalizing Behaviours } & SVI & 59 & $4(0-12)$ & \multirow{2}{*}{$-1,883$} & \multirow{2}{*}{0,060} \\
\hline & TDS & 67 & $2(0-12)$ & & \\
\hline \multirow{2}{*}{$\begin{array}{l}\text { Problem Behaviours } \\
\text { Scale }\end{array}$} & SVI & 59 & $9(1-33)$ & \multirow{2}{*}{$-3,315$} & \multirow{2}{*}{$0,001^{\star \star}$} \\
\hline & TDS & 67 & $5(0-36)$ & & \\
\hline
\end{tabular}

SVI: Students with visual impairments, TDS: Typically developing students

${ }^{*}: p<0,05 \quad * *: p<0,01^{* * *}: p<0.001$

Table 4. shows that externalizing problem behaviour score and the overall problem behaviours of students with visual impairments were significantly higher than their typically developing peers' $(p<0,01)$. However, internalizing problem behaviours of students with visual impairments did not differ from their typically developing peers' significantly $(p>0,05)$. When the scores obtained from internalizing behaviour sub-scale were examined, results showed that the median value of students with visually impairments were higher than their typically developing peers' scores of internalizing behaviours but the difference was not significant. 


\subsection{Do Problem Behaviours Of Students With Visual Impairments Differ Based On Students' Age?}

Problem behaviours scores of the students with visual impairments were examined based on students' age. A Kruskal Wallis Test was used to compare the problem behaviours of students with visual impairments based on their age The results were shown in Table 5.

Table 5. Examination of the social skills of students with visual impairments based on age.

\begin{tabular}{|c|c|c|c|c|c|c|}
\hline Scale and subscales & Age & $\mathrm{N}$ & $\begin{array}{c}\text { Median } \\
\text { (Max-Min) }\end{array}$ & Chi-Square & $\mathrm{p}$ & Difference \\
\hline \multirow{5}{*}{$\begin{array}{l}\text { Externalizing } \\
\text { Behaviours }\end{array}$} & 7 & 4 & $8,5(1-17)$ & \multirow{5}{*}{1,599} & \multirow{5}{*}{0,809} & \multirow{5}{*}{ - } \\
\hline & 8 & 14 & $3,5(1-13)$ & & & \\
\hline & 9 & 16 & $7(0-11)$ & & & \\
\hline & 10 & 11 & $9(1-20)$ & & & \\
\hline & 11 & 14 & $5,5(0-24)$ & & & \\
\hline \multirow{5}{*}{$\begin{array}{l}\text { Internalizing } \\
\text { Behaviours }\end{array}$} & 7 & 4 & $4,5(1-8)$ & \multirow{5}{*}{3,329} & \multirow{5}{*}{0,504} & \multirow{5}{*}{ - } \\
\hline & 8 & 14 & $3,5(1-6)$ & & & \\
\hline & 9 & 16 & $2,5(0-7)$ & & & \\
\hline & 10 & 11 & $4(0-10)$ & & & \\
\hline & 11 & 14 & $4,5(0-12)$ & & & \\
\hline \multirow{5}{*}{$\begin{array}{l}\text { Problem } \\
\text { Behaviours Scale }\end{array}$} & 7 & 4 & $12(5-24)$ & \multirow{5}{*}{2,360} & \multirow{5}{*}{0,670} & \multirow{5}{*}{ - } \\
\hline & 8 & 14 & $7(3-18)$ & & & \\
\hline & 9 & 16 & $9(1-18)$ & & & \\
\hline & 10 & 11 & $14(2-30)$ & & & \\
\hline & 11 & 14 & $8,5(1-33)$ & & & \\
\hline
\end{tabular}

Table 5. shows that externalizing, internalizing and overall problem behaviours scores of students with visual impairments did not differ significantly based on the students' age ( $p>0,05)$.

\subsection{Do Problem Behaviours Of Students With Visual Impairments Differ Based On Students' Gender?}

Problem behaviours of students with visual impairments were compared based on their genders. A Mann Whitney-U test was used to compare the social skills scores of students based on their gender. The results were shown in Table 6.

Table 6. Examination of problem behaviours of students with visual impairments based on their gender.

\begin{tabular}{|c|c|c|c|c|c|}
\hline Scales and subscales & Gender & $\mathbf{N}$ & Median (Min-Max) & $\mathbf{Z}$ & $p$ \\
\hline \multirow{2}{*}{ Externalizing Behaviours } & Female & 26 & $4(0-20)$ & \multirow{2}{*}{$-1,257$} & \multirow{2}{*}{0,209} \\
\hline & Male & 33 & $7(0-24)$ & & \\
\hline \multirow{2}{*}{ Internalizing Behaviours } & Female & 26 & $3,5(0-12)$ & \multirow{2}{*}{$-0,255$} & \multirow{2}{*}{0,799} \\
\hline & Male & 33 & $4(0-9)$ & & \\
\hline \multirow{2}{*}{$\begin{array}{l}\text { Problem Behaviours } \\
\text { Scale }\end{array}$} & Female & 26 & $8(1-30)$ & \multirow{2}{*}{$-0,979$} & \multirow{2}{*}{0,799} \\
\hline & Male & 33 & $9(2-33)$ & & \\
\hline
\end{tabular}

${ }^{*}: p<0,05^{* *}: p<0,01^{* * *}: p<0.001$

Table 6. shows that externalizing, internalizing and overall problem behaviours scores did not differ based on gender of students with visual impairments $(p>0,05)$.

\subsection{Do Problem Behaviours Of Students With Visual Impairments Differ Significantly Based On Students' Grade Levels?}

Problem behaviours of students with visual impairments were examined based on their current grade levels. A Kruskal Wallis Test was used to compare the social skills scores of students based on their grade levels. The results were shown in Table 7. 
Table 7. Examination of problem behaviours of students with visual impairments based on their grade level.

\begin{tabular}{|c|c|c|c|c|c|c|}
\hline Scale and sub-scales & $\begin{array}{l}\text { Grade } \\
\text { level }\end{array}$ & $\mathbf{N}$ & $\begin{array}{c}\text { Median } \\
\text { (Min - Max.) }\end{array}$ & $\begin{array}{l}\text { Chi- } \\
\text { Square }\end{array}$ & $\mathbf{P}$ & Difference \\
\hline \multirow{4}{*}{ Externalizing Behaviours } & 1.grade & 6 & $12(1-17)$ & \multirow{4}{*}{1,785} & \multirow{4}{*}{0,618} & \multirow{4}{*}{-} \\
\hline & 2.grade & 15 & $4(1-11)$ & & & \\
\hline & 3.grade & 15 & $7(0-18)$ & & & \\
\hline & 4.grade & 23 & $6(0-24)$ & & & \\
\hline \multirow{4}{*}{ Internalizing Behaviours } & 1.grade & 6 & $5(1-8)$ & \multirow{4}{*}{8,269} & \multirow{4}{*}{$0,041^{*}$} & \multirow{4}{*}{$1-3$} \\
\hline & 2.grade & 15 & $3(1-6)$ & & & \\
\hline & 3.grade & 15 & $2(0-7)$ & & & \\
\hline & 4.grade & 23 & $4(0-12)$ & & & \\
\hline \multirow{4}{*}{$\begin{array}{l}\text { Problem Behaviour } \\
\text { Scale }\end{array}$} & 1.grade & 6 & $17,5(5-24)$ & \multirow{4}{*}{3,724} & \multirow{4}{*}{0,293} & \multirow{4}{*}{-} \\
\hline & 2.grade & 15 & $8(3-16)$ & & & \\
\hline & 3.grade & 15 & $8(1-20)$ & & & \\
\hline & 4.grade & 23 & $11(1-33)$ & & & \\
\hline
\end{tabular}

${ }^{*}: p<0,05{ }^{* *}: p<0,01^{* * *}: p<0.001$

Table 7 shows that internalizing behaviours scores of first grade students with visual impairments were significantly higher than third grade students $(p<0,05)$. Externalizing and overall problem behaviours of students with visual impairments did not differ based on their current grade levels $(p>0,05)$.

\subsection{Do Problem Behaviours Of Students With Visual Impairments Differ Significantly Based On The Degree Of Students' Visual Impairments?}

Problem behaviours of students with visual impairments were compared based on the degree of visual impairments. A Mann Whitney-U test was used to compare the problem behaviour scores of students with visual impairments based on the degree of visual impairments. The results were shown in Table 8.

Table 8. Comparison of problem behaviours of students with visual impairments based on the degree of visual impairments.

\begin{tabular}{|c|c|c|c|c|c|}
\hline Scales and subscales & $\begin{array}{c}\text { Degree of visual } \\
\text { impairments }\end{array}$ & $\mathbf{N}$ & $\begin{array}{l}\text { Median }_{\text {Max })} \text { (Min- } \\
\end{array}$ & $\mathbf{Z}$ & $\mathbf{p}$ \\
\hline \multirow[b]{2}{*}{$\begin{array}{l}\text { Externalizing } \\
\text { Behaviours }\end{array}$} & Low vision & 26 & $7(0-24)$ & \multirow[b]{2}{*}{$-1,019$} & \multirow[b]{2}{*}{0,308} \\
\hline & $\begin{array}{l}\text { Severe } \\
\text { visual impairments }\end{array}$ & 33 & $6(0-18)$ & & \\
\hline \multirow[b]{2}{*}{ Internalizing Behaviours } & Low vision & 26 & $3,5(0-10)$ & \multirow[b]{2}{*}{$-0,671$} & \multirow[b]{2}{*}{0,502} \\
\hline & $\begin{array}{l}\text { Severe } \\
\text { visual impairments }\end{array}$ & 33 & $4(0-12)$ & & \\
\hline \multirow[b]{2}{*}{$\begin{array}{l}\text { Problem } \\
\text { Scale }\end{array}$} & Low vision & 26 & $10,5(2-33)$ & \multirow[b]{2}{*}{$-1,009$} & \multirow[b]{2}{*}{0,313} \\
\hline & $\begin{array}{l}\text { Severe } \\
\text { visual impairments }\end{array}$ & 33 & $8(1-24)$ & & \\
\hline
\end{tabular}

Table 8 shows that the externalizing, internalizing and overall problem behaviours of students with visual impairments did not differ significantly based on the degree of students' visual impairments (low vision or severe visual impairments) $(p>0,05)$. 


\section{DISCUSSION}

The main purpose of the current study was to compare the problem behaviours of students with visual impairments with problem behaviours of typically developing peers. The Social Skills Rating System Turkish Form (Gresham \& Elliot, 1990; Sucuoglu \& Ozokcu, 2005) was used to collect the study data. The findings of the current study indicated that externalizing behaviors and overall problem behaviours of the students with visual impairments were significantly higher than typically developing students' problem behaviour scores. In addition, internalizing behaviours of students with visual impairments were found to be higher than their typically developing peers internalizing behaviours. However, this difference was not significant statistically. Ozdemir (2013) states that externalizing and internalizing behaviours are interrelated and emphasizes the transitivity between internalizing and externalizing behaviours. Therefore, externalizing behaviours of students with visual impairments should be taken into consideration in order to prevent internalizing behaviours of students with visual impairments that may occur in their later periods of lives. Current study found that problem behaviours of students with visual impairments did not differ based on students' age, gender and the degree of visual impairments (low vision or severe visual impairments). Although grade levels had some effects on the problem behaviours of students with visual impairments, this was not a gradually increasing effect on problem behaviours of students with visual impairments.

Buhrow, Hartshorne, and Bradley-Johnson (1998) compared the problem behaviours of students with visual impairments with their typically developing peers. Researchers found that although overall social skills of students with visual impairments were not lower than their typically developing peers, some sub-scale scores of students with visually impairments were lower than their peers. Buhrow et al., (1998) also found that problem behaviour scores of students with visual impairments were higher and academic competency scores of students with visual impairments were lower than their peers. Ozkubat (2010) examined the social skills, problem behaviours and academic competency scores of the students with visual impairments in Turkey. The findings of the study indicated that social skills and academic competency scores of students with visual impairments were lower than typically developing peers' scores and problem behaviours of students with visual impairments were higher than typically developing students' scores. In general, studies that explore the problem behaviours of students with visual impairments conducted in Turkey are very few. The findings of the current study were consistent with other studies both conducted in Turkey and in Western cultures (Buhrow et al., 1998; Ozkubat, 2010; Sucuoglu \& Ozokcu, 2005). As students with visual impairments may lack necessary social skills (Ozdemir, 2009; Ozdemir \& Ataman, 2010; Ozkubat \& Ozdemir, 2012; Ozdemir et al. 2011), such difficulties may lead problem behaviours to students with visual impairments. Though there have not been enough evidence indicating cause and effect relation between social skills and problem behaviours in children with visual impairments in Turkey, it is widely accepted that problem behaviours may arise from social skills deficits.

In the current study, problem behaviours of students with visual impairments were examined based on students' age, gender, and grade levels. Sucuoglu and Ozokcu (2005) found that overall problem behaviour scores of female students with special needs were significantly lower than their male peers. No significant differences based on gender was found in internalizing problem behaviours in the study. Sucuoglu and Ozokcu (2005) also found that grade levels had no effect on problem behaviours of students with special needs. The current study showed some group differences based on the problem behaviours of students with visual impairments. However, this was not a consistent effect across all grade levels. Age was not a significant factor on problem behaviours of students with visual impairments as well. One may expect that while grade levels or age increases the intensity of the problem behaviours may decrease due to maturation. However, when we consider the isolated environments in which students with visual impairments educated in schools in Turkey, the effects of the maturation cannot be seen as expected. Another issue explored in the current study was the effects of the degree of visual impairments on the problem behaviours of students with visual impairments. The degree of visual impairments, having low vision or severe visual impairments, had no significant effect on the problem behaviours of students with visual impairments.

To summarize, this was an important study in regard to its findings. As noted above, only few studies conducted in Turkey explored the problem behaviours of students with visual impairments. This study provides evidence base needed to design effective interventions to decrease problem behaviours and increase appropriate social skills of students with visual impairments.

\subsection{Recommendations For Future Research And Practice}

In this study, the study data were obtained based on the teacher ratings about the problem behaviours of students with visual impairments. In future studies, different groups such as parents or students by 
themselves could rate problem behaviours. The current study used the SSRS as a data collection tool. However various data collection techniques such as direct observations can be used to collect study data.

Overall, the results of the study suggest for a need for effective interventions to decrease problem behaviours of students with visual impairments. Developing screening protocols for problem behaviours of students with visual impairments is also important to intervene the problem behaviours of students as early as possible.

\section{REFERENCE LIST}

Ageranioti-Bélanger, S., Brunet, S., D’Anjou, G., Tellier, G., Boivin, J., \& Gauthier, M. (2012). Behaviour disorders in children with an intellectual disability. Paediatrics \& Child Health, 17(2), 84.

Alimovic, S. (2013). Emotional and behavioural problems in children with visual impairment, intellectual and multiple disabilities. Journal of Intellectual Disability Research, 57(2), 153-160.

Aykır, T., (2010). Okul Öncesi Dönemdeki Zihinsel Yetersizliği Olan ve Olmayan Çocujkların Sosyal Becerilerinin ve Problem Davranışlarının Karşılaştııılması. Unpublished master's thesis. Abant İzzet Baysal Üniversitesi, Sosyal Bilimler Enstitüsü, Bolu.

Buhrow, M. M., Hartshorne, T. S., \& Bradley-Johnson, S. (1998). Parents' and teachers' ratings of the social skills of elementary-age students who are blind. Journal of Visual Impairment and Blindness, 92, 503511.

Cicchetti, D., \& Toth, S. L. (1991). A developmental perspective on internalizing and externalizing disorders. In D. Cicchetti, \& S. L. Toth (Eds.), Internalizing and externalizing expressions of dysfunction (pp. 1 19). New York Erlbaum. Retrieved from https://books.google.com.tr/books?hl=tr\&lr=\&id=WejJAgAAQBAJ\&oi=fnd\&pg=PA1\&ots=ec8DiPapKq\&

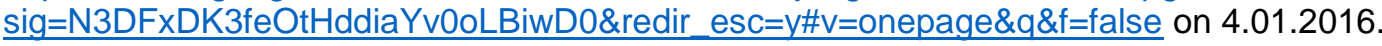

Dekker, M. C., Koot, H. M., Ende, J. V. D., \& Verhulst, F. C. (2002). Emotional and behavioral problems in children and adolescents with and without intellectual disability. Journal of Child Psychology and Psychiatry, 43(8), 1087-1098.

Elgar, F. J., Arlett, C., \& Groves, R. (2003). Stress, coping, and behavioural problems among rural and urban adolescents. Journal of Adolescence, 26(5), 574-585.

Orhan, M. (2010). Okulöncesi kaynaştırma öğrencileriyle normal gelişim gösteren öğrencilerin sosyal beceri ve problem davranışlarının düzeyi ile öğretmenlerin kaynaştırmaya ilişkin görüşlerinin incelenmesi. Unpublished master's thesis. Anadolu Üniversitesi, Eğitim Bilimleri Enstitüsü, Eskişehir.

Ozdemir, S. (2009). Görme yetersizliği olan cocuklar ile tipik gelisim gösteren çocukların sosyal becerilerinin karşılaştırılması. Paper presented at 19. Ulusal Ozel Eğitim Kongresi, Marmaris, Muğla.

Ozdemir, S., Gurel, O., Ceyhun, A.T., Sahin, R., ve Küçüközyiğit, M. S. (2011). Okul öncesi dönemde görme engelli çocuklarla normal gelişim gösteren çocukların oyun davranışlarının karşılaştırılması, Paper presented at 21. Ulusal Özel Eğitim Kongresi, Kıbrıs.

Ozdemir, S. (2013). Duygu Davranış Bozukluğu Olan Öğrenciler. In I.H. Diken (ed.) Özel Eğitime Gereksinimi Olan Öğrenciler ve Özel Eğitim (pp. 370-407). Pegem Akademi: Ankara.

Ozdemir, S. ve Ataman, A. (2010). Görme yetersizliğinden etkilenen çocukların sosyal beceri yetersizliği. Paper presented at 20. Ulusal Ozel Eğitim Kongresi, Gaziantep.

Ozkubat, U., \& Özdemir, S. (2012). Görme yetersizliğinden etkilenmiş ve normal gelişim gösteren çocukların sosyal becerilerinin karşılaştırılması. Ankara Üniversitesi Özel Eğitim Dergisi, 13(1), 1-14.

Perle, J. G., Levine, A. B., Odland, A. P., Ketterer, J. L., Cannon, M. A., \& Marker, C. D. (2013). The association between internalizing symptomology and risky behaviors. Journal of Child \& Adolescent Substance Abuse, 22(1), 1-24.

Rubin, K. H., Chen, X., McDougall, P., Bowker, A., \& McKinnon, J. (1995). The Waterloo Longitudinal Project: Predicting internalizing and externalizing problems in adolescence. Development and Psychopathology, 7(04), 751-764.

Sucuoglu, B. (2003). Sorun davranışlar kontrol listesi Türkçe formunun psikometrik özelliklerinin incelenmesi. Türk Psikoloji Dergisi, 18(52), 77-91. 
Sucuoglu, B. ve Kargın, T. (2006). Ilköğretimde Kaynaştırma Uygulamaları. İstanbul: Morpa Yayınları.

Sucuoglu, B., \& Ozokcu, O. (2005). Kaynaştırma öğrencilerinin sosyal becerilerinin değerlendirilmesi. Ankara Üniversitesi Eğitim Bilimleri Fakültesi Özel Eğitim Dergisi, 6(1), 41-57.

Sugai, G., Horner, R. H., Dunlap, G., Hieneman, M., Lewis, T. J., Nelson, C. M., \& Turnbull, H. R. (2000). Applying positive behavior support and functional behavioral assessment in schools. Journal of Positive Behavior Interventions, 2(3), 131-143.

Vossekuil, B., Fein, R. A., Reddy, M., Borum, R., \& Modzeleski, W. (2002). The final report and findings of the safe school initiative: Implications for prevention of school attacks in the United States. Washington, DC: U.S. Secret Service and U.S. Department of Education. Retrieved from http://www2.ed.gov/admins/lead/safety/preventingattacksreport.pdf on 29.12.2015

Vuran, S. (2013). Davranış problemleri ile baş etmek. In I. H. Diken (ed.), Illköğretimde Kaynaştırma (pp. 260289). Ankara: Pegem Akademi.

Walker, H. M., Ramsey, E., \& Gresham, R. M. (2005). Antisocial behavior in school: Evidence-based practices. Belmont, CA: Wadsworth/Thomson Learning.

Welcome, K. (2013). The Externalizing and Internalizing Behaviors in Children Preventing Negative Future Consequences. Retrieved from http://legacy.usfsm.edu/academics/cas/capstone/20122013/interdisciplinary\%20social\%20sciences/welcomethe $\% 20$ externalizing\%20and\%20\%20\%20internalizing $\% 20$ behavior\%20in\%20children.pdf?from=404 on 27.12.2015.

Yosumaz, K. (2013). Okul öncesi eğitim kurumlarına devam eden (60-72 ay) zihinsel engelli ve normal gelişim gösteren çocukların problem davranışlarının çeşitli değişkenlere göre karşılaştırılması. Unpublished master's thesis. Dumlupınar Üniversitesi, Eğitim Bilimleri Enstitüsü, Kütahya. 